\title{
Childhood Diffuse Large Cell Lymphoma
}

National Cancer Institute

\section{Source}

National Cancer Institute. Childhood Diffuse Large Cell Lymphoma. NCI Thesaurus. Code C9076.

A diffuse large cell lymphoma occurring in children. 